\author{
Л.Р. ШОСТАКОВИЧ-КОРЕЦЬКА \\ І.В. ЧУХАЛОВА'
}

\title{
ОСОБЛИВОСТІ ПОРУШЕННЯ КОГНІТИВНОЇ ФУНКЦІї У ПАЦІЄНТІВ ІЗ ВІЛ-ІНФЕКЦІЄЮ, ЯКІ ПЕРЕБУВАЮТЬ ПІД АМБУЛАТОРНИМ НАГЛЯДОМ
}

\author{
${ }^{1}$ Д3 «Дніпропетровська медична академія МОЗ України», м. Дніпро, Україна \\ ${ }^{2}$ КЗ «Дніпропетровський обласний центр з профрілактики та боротьби зі СНІДом», м. Дніпро, Україна \\ ${ }^{3}$ К3 «Дніпропетровська міська клінічна лікарня № 21 ім. проф. Є.Г. Попкової» ДОР», м. Дніпро, Україна
}

\begin{abstract}
Мета: визначити наявність когнітивних порушень та фактори можливого впливу на когнітивну функцію серед пацієнтів із ВІЛ, які перебувають під амбулаторним наглядом.

Матеріали і методи. До дослідження залучено 95 пацієнтів із підтвердженою ВІЛ-іноекцією без клінічних ознак захворювань ЦНС. Оцінку ментального статусу проводили за результатами проходження 2 тестів: MMSE (MiniMental State Examination) та «малювання годинника».

Результати. Виявлено, що зменшення частоти когнітивних розладів корелювало із тривалістю антиретровірусної терапії - коесріцієнт кореляції для бальної оцінки за шкалою MMSE становив rs=+0,27, p<0,01, для тесту «малювання годинника» - rs=+0,22, p<0,05. Визначено тенденцію до збільшення частоти когнітивних порушень при застосуванні ефравірензу. Встановлено, що застосування замісної підтримувальної терапії (метадон) у споживачів наркотиків зменшувало відносний ризик розвитку когнітивних розладів $(p<0,01)$. Визначено наявність вірогідного зв'язку когнітивних розладів із вірусним навантаженням у динаміці спостереження ( $r s=-0,20, p<0,05$ для тесту MMSE).

Висновки. Порушення когнітивної фрункції мають місце у ВІЛ-позитивних пацієнтів вже на ранній стадії ВІЛіндекції.
\end{abstract}

КЛЮЧОВІ СЛОВА: ВІЛ-інфекція; когнітивні порушення; антиретровірусна терапія; замісна підтримувальна терапія.

Вважається, що помірні когнітивні розлади $є$ загальною ознакою хронічної ВІЛ-інфекції незалежно від рівня вірусного навантаження та кількості СД4 клітин [8]. Автори існуючих робіт припускають, що ці розлади відбуваються у 30-50 \% пацієнтів залежно від когорти дослідження та методів, які виявляють ці порушення $[3,6-8,11,13]$. Розвиток когнітивних порушень не виключений у пацієнтів, які отримують високоактивну антиретровірусну терапію (АРТ) [3]. Ряд авторів довів високу поширеність нейрокогнітивних порушень у безсимптомних ВІЛ-інфікованих осіб, пов'язану з використанням ефавірензу, що свідчить про потенційну нейротоксичність цього препарату [4]. Antinori A. et al. [14] назвали ВІЛ-асоційований нейрокогнітивний розлад «безсимптомним нейрокогнітивним порушенням», коли його виявляють при тестуванні за відсутності симптомів, та «м'яким нейрокогнітивним розладом», коли наявні і ознаки, і симптоми, але не достатньо суттєві, щоб сформувати відверту деменцію. Вважається, що скринінг для когнітивних порушень як у ВІЛ-позитивній, так і у ВІЛ-негативній популяціях $€$ суперечливою темою [15]. $€$ розбіжності в думках різних авторів відносно використання міні-ментальної схеми дослідження психічного стану або тесту Фолштейна (Mini-Mental State Examination - MMSE) $[2,5,10]$, яка спочатку була розроблена, щоб диференціювати пацієнтів із функціональними та органічними деменціями, і насамперед випробує «кіркові» ссрери. За допомогою тесту MMSE вивчають увагу, розрахунок, мову, сприйняття, здатність виконувати прості команди та орієнтацію [5]. Ряд авторів наводив переваги тесту «малювання годинника» як скринінговий тест на деменцію, відзначаючи його простоту, більшу чутливість, швидкість, меншу залежність від рівня освіти, краще сприйняття пацієнтами та відсутність необхідності для мовної адаптації $[1,2,9,12]$. Тест «малювання годинника» $€$ одним із найпоширеніших та найпростіших нейропсихологічних методів тестування, за допомогою якого можливо досить швидко дослідити організацію довільної діяльності та просторову фуннкцію вищої психічної діяльності $[9,12]$. У той же час, більшість рекомендацій щодо лікування ВІЛ-інфекції не містить жодних конкретних вказівок щодо проведення скринінгу [15]. Так, наприклад, метод скринінгу Європейського клінічного товариства СНІД (European

(с Л.Р. Шостакович-Корецька, К.Ю. Литвин, О.О. Білоконь, І.П. Мішкой, І.В. Чухалова, О.О. Ліснича, 2018 
AIDS Clinical Society - EACS) включає відповіді на три запитання: «Чи часто виникають втрати пам'яті?»; «Чи ви відчуваєте, що ви повільніші при міркуваннях, плануванні діяльності чи вирішенні проблем?» та «Чи виникають труднощі, приділяючи увагу?». Відповіді «так, безумовно», принаймні, є позитивним тестом на перевірку, що, може бути недостатнім для оцінки статусу та вимагає подальшого дослідження. ВООЗ рекомендує [16], щоб для ключових груп людей, які живуть з ЛЖВ, проводити регулярний моніторинг розладів психічного здоров'я для оптимізації медичних результатів та покращення дотримання АРТ. Не виключено, що комплексне використання когнітивних тестів може мати більшу чутливість стосовно пацієнтів із ВІЛ-інфекцією, які не мають клінічно виражених ознак неврологічних розладів.

Мета дослідження: визначити наявність когнітивних порушень за допомогою спеціальних тестів та фрактори можливого впливу на когнітивну функцію серед пацієнтів із ВІЛ, які перебувають під диспансерним наглядом.

Матеріали і методи. До дослідження залучено 95 пацієнтів, віком від 23 до 65 років (середній вік - $(42,4 \pm 0,9)$ року), $з$ підтвердженою ВІЛінфекцією, які перебувають під диспансерним наглядом у Дніпропетровському міському та обласному центрах із профрілактики і боротьби зі СНІД, та не мали на час обстеження клінічних ознак захворювань ЦНС. Основні характеристики групи дослідження наведено в таблиці 1.

Таблиця 1. Характеристики пацієнтів із ВІЛ-інфекцією (n=95)

\begin{tabular}{|c|c|c|}
\hline \multicolumn{2}{|r|}{ Характеристики } & Значення \\
\hline \multicolumn{2}{|c|}{ 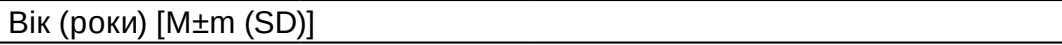 } & $42,4 \pm 0,9(8,9)$ \\
\hline \multicolumn{2}{|c|}{ Вік $\geq 50$ років [n (\%)] } & $22(23,2 \%)$ \\
\hline \multirow[t]{2}{*}{ Стать [n (\%)] } & чоловіча & $57(60,0 \%)$ \\
\hline & жіноча & $38(40,0 \%)$ \\
\hline \multirow{3}{*}{$\begin{array}{l}\text { Клінічна стадія ВІЛ } \\
\text { [n (\%)]: }\end{array}$} & $1-2$ & $20(21,1 \%)$ \\
\hline & 3 & $18(18,9 \%)$ \\
\hline & 4 & $57(60,0 \%)$ \\
\hline \multicolumn{2}{|c|}{ 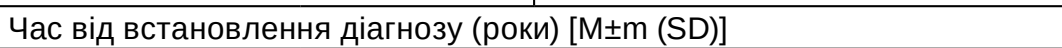 } & $6,40 \pm 0,42(4,09)$ \\
\hline \multicolumn{2}{|c|}{ 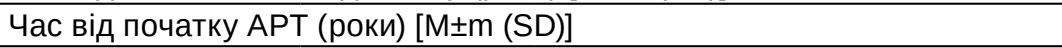 } & $4,48 \pm 0,32(3,11)$ \\
\hline \multicolumn{2}{|c|}{ У даний час на АРТ [n (\%)] } & $92(96,8 \%)$ \\
\hline \multicolumn{2}{|c|}{ Використання ефравірензу [n (\%)] } & $46(48,4 \%)$ \\
\hline \multicolumn{2}{|c|}{ Використання долутегравіру [n (\%)] } & $10(10,5 \%)$ \\
\hline \multicolumn{2}{|c|}{ Використання наркотиків (код 102) [n (\%)] } & $53(55,8 \%)$ \\
\hline \multicolumn{2}{|c|}{ Замісна терапія (приймання метадону) [n (\%)] } & $30(31,6 \%)$ \\
\hline \multicolumn{2}{|c|}{ Поточне вірусне навантаження (ВІЛ РНК копії/мл) [Me (IQR)] } & $40(40-40)$ \\
\hline \multicolumn{2}{|c|}{$\begin{array}{l}\text { Первинне вірусне навантаження ВІЛ РНК } \\
\text { [Me (IQR)] }\end{array}$} & $\begin{array}{c}87093 \\
(25385-336576)\end{array}$ \\
\hline \multicolumn{2}{|c|}{ Поточний рівень СД4 (клітини/мкл) [Me (IQR)] } & $424(287-614)$ \\
\hline \multicolumn{2}{|c|}{ Nadir кількість СД4 (клітини/мкл) [Me (IQR)] } & $164(81-367)$ \\
\hline \multirow{2}{*}{$\begin{array}{l}\text { Наявність в } \\
\text { анамнезі: }\end{array}$} & перенесених неврологічних уражень ЦНС [n (\%)] & $7(7,4 \%)$ \\
\hline & хронічного вірусного гепатиту [n (\%)] & $32(33,7 \%)$ \\
\hline
\end{tabular}

Оцінку ментального статусу проводили за результатами проходження 2 тестів: MMSE та «малювання годинника».

Результати тесту MMSE оцінювали за кількістю набраних балів [10]:

- 28-30 - немає порушень когнітивних фрункцій;

- 24-27 - переддементні когнітивні порушення;

- 20-23 - деменція легкого ступеня;

- 11-19 - деменція помірного ступеня;

- 0-10 - тяжка деменція.

Тест «малювання годинника» проводили таким чином. Пацієнту пропонували намалювати годинник, стрілки якого вказували на певний час. У нормі пацієнт малює коло, розставляє всередині нього цифри від 1 до 12 у правильному порядку 3 рівними інтервалами, зображує 2 стрілки (годинникову коротше, хвилинну довше), що починаються в центрі й показують заданий час [1]. Відхилення від правильного виконання тесту розцінювали як ознаки когнітивної дисфункції, ступінь якої оцінювали за наступною шкалою (бали були тесту зворотно конвертовані нами для зручності проведення паралельного аналізу зі шкалою MMSE).

- «деально»: числа від 1 до 12 розставлені правильно; годинник має дві стрілки і показує правильний час (6 балів).

- Невеликі видимі просторові помилки: інтервали між числами нерівні; числа намальовані поза колом; повертав лист під час малювання таким чином, що деякі числа виявилися перевернутими 
догори ногами; намальовані лінії для орієнтації («спиці») (5 балів).

- Помилка в позначенні часу (рисунок годин візуально і просторово виглядає нормально): пропущена одна стрілка; час написаний словами; час не відзначено (4 бали).

- Візуальна просторова дезорганізація середнього ступеня, у зв'язку з чим неможливо правильно відобразити час: порушення розташування середнього ступеня; пропущені числа; персеверація: повторно малює коло, продовжує ставити цифри після 12 (13, 14, 15 і т. д.); розташування проти годинникової стрілки; дизграфрія: нечитабельне (3 бали).

- Виражена видима просторова дезорганізація: як описано в п. 4, тільки порушення більш виражені (2 бали).

- Годинник не намальований (крім депресії і психотичного стану): неможливо зробити раціональну спробу намалювати годинник; немає подібності 3 годинником; пацієнт пише слова або назви (1 бал).

Статистичну обробку результатів дослідження проводили з використанням пакету прикладних програм STATISTICA v.6.1®. З урахуванням закону розподілу кількісних ознак (критерій КолмогороваСмірнова 3 поправкою Лілієфорса) використовували параметричні та непараметричні характеристики і методи порівняння: для нормального закону розподілу - середнє арифрметичне (М), стандартну похибку (m), стандартне відхилення (SD), критерій Стьюдента (t); в інших випадках - медіану (Ме), інтерквартильний інтервал (interquartile range - IQR), критерій Манна-Уїтні (U). Порівняння відносних показників проводили за критерієм $X^{2}$-Пірсона і двостороннім точним критерієм Фішера (FET). Виконували кореляційний аналіз із розрахунком коефіцієнтів рангової кореляції Спірмена (rs). Критичний рівень статистичної значимості при перевірці гіпотез приймали $<5 \%(p<0,05)$.

Результати дослідження та їх обговорення. Порівняльний аналіз ментального статусу у ВІЛпозитивних пацієнтів за тестами MMSE та «малювання годинника» показав їх узгодженість за оцінками ступеня порушень когнітивних функцій коефріцієнт кореляції rs=+0,72, p<0,001. За даними обох тестів, у більшості хворих (77 осіб 81,1 \%) показники когнітивних функцій або відповідали нормі (56,9 \% за MMSE і 73,7\% за малюванням), або мали відхилення, розцінені як переддементні порушення (24,2 і 7,4% відповідно).

Ми не виявили вірогідного зв'язку між ступенем когнітивних порушень та стадією ВІЛ-інфрекції (табл. 2), що можна пояснити тривалістю спостереження та наявністю АРТ в анамнезі пацієнтів 3 та 4 стадій.

Визначено, що зменшення частоти когнітивних розладів корелювало із тривалістю АРТ - коефіцієнт кореляції для бальної оцінки за шкалою MMSE становив rs=+0,27, p<0,01, для тесту «малювання годинника» - rs=+0,22, p<0,05, що свідчить про протекторний ефект АРТ відносно виникнення та прогресування когнітивних порушень. Так, середній бал за шкалою MMSE для пацієн-

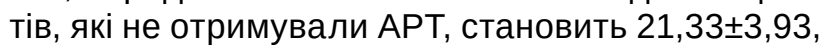
у пацієнтів із тривалістю терапії до одного року $26,58 \pm 0,67$ ( $p<0,05$ порівняно 3 попередньою групою), при тривалості АРТ від 5 до 10 років -

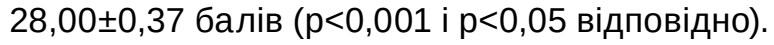

Таблиця 2. Ступінь вираження порушень когнітивних функцій залежно від стадії ВІл-інфрекції (n=95)

\begin{tabular}{|c|c|c|c|c|c|}
\hline \multirow{2}{*}{ Ступінь порушень } & \multirow{2}{*}{ Тест } & \multirow{2}{*}{ Бали } & \multicolumn{3}{|c|}{ Клінічна стадія ВІЛ, кількість хворих, n (\%) } \\
\hline & & & $1-2(n=20)$ & $3(n=18)$ & $4(n=57)$ \\
\hline \multirow{2}{*}{$\begin{array}{l}\text { Немає порушень } \\
\text { когнітивних функцій }\end{array}$} & MMSE & $28-30$ & $12(60,0 \%)$ & $10(55,6 \%)$ & $32(56,1 \%)$ \\
\hline & $\begin{array}{c}\text { Малювання } \\
\text { годинника }\end{array}$ & 6 & $15(75,0 \%)$ & $11(61,1 \%)$ & $44(77,2 \%)$ \\
\hline \multirow{2}{*}{$\begin{array}{l}\text { Переддементні } \\
\text { когнітивні порушення }\end{array}$} & MMSE & $24-27$ & $5(25,0 \%)$ & $2(11,1 \%)$ & $16(28,1 \%)$ \\
\hline & $\begin{array}{c}\text { Малювання } \\
\text { годинника }\end{array}$ & 5 & $2(10,0 \%)$ & $2(11,1 \%)$ & $3(5,3 \%)$ \\
\hline \multirow{2}{*}{$\begin{array}{l}\text { Деменція легкого } \\
\text { ступеня }\end{array}$} & MMSE & $20-23$ & $2(10,0 \%)$ & $6(33,3 \%)$ & $7(12,3 \%)$ \\
\hline & $\begin{array}{c}\text { Малювання } \\
\text { годинника }\end{array}$ & 4 & - & $2(11,1 \%)$ & $3(5,3 \%)$ \\
\hline \multirow{2}{*}{$\begin{array}{l}\text { Деменція помірного } \\
\text { ступеня }\end{array}$} & MMSE & $11-19$ & $1(5,0 \%)$ & - & $2(3,5 \%)$ \\
\hline & $\begin{array}{c}\text { Малювання } \\
\text { годинника }\end{array}$ & $2-3$ & $1(5,0 \%)$ & $2(11,1 \%)$ & $4(7,0 \%)$ \\
\hline \multirow[t]{2}{*}{ Тяжка деменція } & MMSE & $0-10$ & - & - & - \\
\hline & $\begin{array}{c}\text { Малювання } \\
\text { годинника }\end{array}$ & 1 & $2(10,0 \%)$ & $1(5,6 \%)$ & $3(5,3 \%)$ \\
\hline
\end{tabular}

Водночас, за результатами дослідження визначена тенденція до збільшення частоти когнітивних порушень у ВІЛ-інфрікованих осіб при застосуванні есравірензу порівняно з тими, хто приймав інші препарати АРТ, що пов'язано з нейротоксичним есректом означеного препарату. Так, ознаки де- 
менції різного ступеня за тестом MMSE мали 13 з 46 пацієнтів (28,3\%), в АРТ яких застосовувався ефравіренз, в іншій групі таких пацієнтів було $5(10,2 \%)(p<0,05)$. За тестом «малювання годинника» зазначені порушення когнітивних фрункцій мали 14 (30,4 \%) і 4 (8,2 \%) пацієнтів, відповідно ( $p<0,01)$. Щодо використання долутегравіру у АРТ тематичних хворих, то нейротоксична дія цього препарату була невираженою - коефіцієнт кореляції для бальної оцінки за шкалою MMSE становив rs=+0,15, p>0,05, для тесту «малювання годинника» - rs=+0,14, p>0,05.

Встановлено, що застосування замісної підтримувальної терапії (метадон) у споживачів наркотиків зменшувало відносний ризик розвитку когнітивних розладів. Зокрема, на тлі замісної терапії у 30 споживачів наркотиків ознаки деменції помірного і тяжкого ступенів за результатами тесту «малювання годинника» не зафіксовані в жодному випадку, в той час, як в іншій групі такі порушення визначені у 6323 пацієнтів $(26,1 \%)(p<0,01)$.
Аналіз зв'язків показників СД4 та вірусного навантаження ВІЛ РНК зі ступенем вираження когнітивних розладів довів наявність вірогідного зв'язку лише 3 вірусним навантаженням у динаміці спостереження ( $r s=-0,20, p<0,05$ для тесту MMSE).

\section{Висновки}

Визначено, що порушення когнітивної функції мають місце майже у половини ВІЛ-позитивних пацієнтів, які спостерігаються амбулаторно, у тому числі на ранній стадії ВІЛ-інфекції. Комплексне використання тестів є більш інформативним для виявлення когнітивної дисорункції у пацієнтів із ВІЛ. Моніторинг розладів психічного здоров'я $€$ корисним для оптимізації спостереження за ВІЛінфікованими пацієнтами та вибору схеми АРТ.

Перспективи подальших досліджень полягають у подальшому розширенні моніторингу розладів психічного здоров'я у ВІЛ-інфікованих пацієнтів.

\section{Список літератури}

1. Clock drawing test ratings by dementia specialists: interrater reliability and diagnostic accuracy / A. K. Nair, B. E. Gavett, M. Damman [et al.] // The Journal of Neuropsychiatry and Clinical Neurosciences. - 2010. - Vol. 22, No. 1. - P. 85-92.

2. Death J. Comparison of clock drawing with Mini Mental State Examination as a screening test in elderly acute hospital admissions / J. Death, A. Douglas, R. A. Kenny // Postgraduate Medical Journal. - 1993. - Vol. 69. No. 815. - P. 696-700.

3. Dynamics of cognitive change in impaired HIV-positive patients initiating antiretroviral therapy / L. A. Cysique, F. Vaida,

S. Letendre [et al.] // Neurology. - 2009 - Vol.73, No. 5. - P. 342-358.

4. Efavirenz associated with cognitive disorders in otherwise asymptomatic HIV-infected patients / N. Ciccarelli, M. Fabbiani,

S. Di Giambenedetto [et al.] // Neurology. - 2011. - Vol. 76, No. 16. - P. 1403-1409.

5. Folstein M. F. "Mini-mental state": a practical method for grading the cognitive state of patients for the clinician / M. F. Folstein, S. E. Folstein, P. R. McHugh // Journal of Psychiatric Research. - 1975. - Vol. 12, No. 3. - P. $189-198$.

6. Hardy D. J. The neuropsychology of HIVIAIDS in older adults / D. J. Hardy, D. E Vance // Neuropsychology Review. 2009. - Vol. 19, No. 2. - P. 263.

7. Higher frequency of dementia in older HIV 1 individuals: the Hawaii aging with HIV-1 cohort / V. Valcour, C. Shikuma, B. Shiramizu [et al.] // Neurology. - 2004. - Vol. 63, No. 5. - P. 822-827.

8. HIV suppression by HAART preserves cognitive function in advanced, immune reconstituted AIDS patients /

J. A. McCutchan, J. W. Wu, K. Robertson [et al.] // AIDS. - 2007. - Vol. 21. - P. 1109-1117.

9. Juby $A$. The value of clock drawing in identifying executive cognitive dysfunction in people with a normal Mini-Mental State Examination score / A. Juby, S. Tench, V. Baker // Canadian Medical Association Journal. - 2002. - Vol. 167, No. 8. - P. 859-864.

10. Pangman V. C. An examination of psychometric properties of the mini-mental state examination and the standardized mini-mental state examination: implications for clinical practice / V. C. Pangman, J. Sloan, L. Guse // Applied Nursing Research. - 2000. - Vol. 13, No. 4. - P. 209-213.

11. Prevalence of cognitive disorders differs as a function of age in HIV virus infection / J. T. Becker, O. L Lopez, M. A. Dew [et al.] // AIDS. - 2004. - Vol. 18. - P. 11-18.

12. The clock drawing test is an independent predictor of incident use of 24-hour care in a retirement community I L. L. Lavery, S. M. Starenchak, W. B. Flynn [et al.] // The Journals of Gerontology Series A: Biological Sciences and Medical Sciences. - 2005. - Vol. 60, No. 7. - P. 928-932.

13. The prevalence and incidence of neurocognitive impairment in the HAART era / K. R. Robertson, M. Smurzynski, T. D. Parsons [et al.] // AIDS. - 2007. - Vol. 21, No. 14. - P. 1915-1921.

14. Updated research nosology for HIV-associated neurocognitive disorders / A. Antinori, G. Arendt, J. T. Becker [et al.] // Neurology. - 2007. - Vol. 69, No. 18. - P. 1789-1799

15. Underwood J. Guidelines for evaluation and management of cognitive disorders in HIV-positive individuals / J. Underwood, A. Winston // Current HIVIAIDS Reports. - 2016. - Vol. 13, No. 5. - P. 235-240.

16. World Health Organization. Consolidated guidelines on HIV prevention, diagnosis, treatment and care for key populations. Geneva: World Health Organization. - 2014. - 174 p. 


\section{References}

1. Nair, A.K., Gavett, B.E., Damman, M., Dekker, W., Green, R.C., Mandel, A., ... \& Stern, R.A. (2010). Clock drawing test ratings by dementia specialists: interrater reliability and diagnostic accuracy. The Journal of Neuropsychiatry and Clinical Neurosciences, 22 (1), 85-92.

2. Death, J., Douglas, A., \& Kenny, R.A. (1993). Comparison of clock drawing with Mini Mental State Examination as a screening test in elderly acute hospital admissions. Postgraduate Medical Journal, 69 (815), 696-700.

3. Cysique, L.A., Vaida, F., Letendre, S., Gibson, S., Cherner, M., Woods, S.P., ... \& Ellis, R.J. (2009). Dynamics of cognitive change in impaired HIV-positive patients initiating antiretroviral therapy. Neurology, 73 (5), 342-348.

4. Ciccarelli, N., Fabbiani, M., Di Giambenedetto, S., Fanti, I., Baldonero, E., Bracciale, L., \& Silveri, M.C. (2011). Efavirenz associated with cognitive disorders in otherwise asymptomatic HIV-infected patients. Neurology, 76 (16), 1403-1409

5. Folstein, M.F., Folstein, S.E., \& McHugh, P.R. (1975). "Mini-mental state": a practical method for grading the cognitive state of patients for the clinician. Journal of Psychiatric Research, 12 (3), 189-198.

6. Hardy, D.J., \& Vance, D.E. (2009). The neuropsychology of HIVIAIDS in older adults. Neuropsychology Review, 19 (2), 263.

7. Valcour, V., Shikuma, C., Shiramizu, B., Watters, M., Poff, P., Selnes, O., ... \& Sacktor, N. (2004). Higher frequency of dementia in older HIV-1 individuals The Hawaii Aging with HIV-1 Cohort. Neurology, 63 (5), 822-827.

8. McCutchan, J.A., Wu, J.W., Robertson, K., Koletar, S.L., Ellis, R.J., Cohn, S., ... \& Williams, P.L. (2007). HIV suppression by HAART preserves cognitive function in advanced, immune-reconstituted AIDS patients. Aids, 21 (9), 1109-1117.

9. Juby, A., Tench, S., \& Baker, V. (2002). The value of clock drawing in identifying executive cognitive dysfunction in people with a normal Mini-Mental State Examination score. Canadian Medical Association Journal, 167 (8), 859-864.

10. Pangman, V.C., Sloan, J., \& Guse, L. (2000). "An Examination of Psychometric Properties of the Mini-Mental Status Examination and the Standardized Mini-Mental Status Examination: Implications for Clinical Practice". Applied Nursing Research, 13 (4), 209-213

11. Becker, J.T., Lopez, O.L., Dew, M.A., \& Aizenstein, H.J. (2004). Prevalence of cognitive disorders differs as a function of age in HIV virus infection. Aids, 18, 11-18.

12. Lavery, L.L., Starenchak, S.M., Flynn, W.B., Stoeff, M.A., Schaffner, R., \& Newman, A.B. (2005). The clock drawing test is an independent predictor of incident use of 24-hour care in a retirement community. The Journals of Gerontology Series A: Biological Sciences and Medical Sciences, 60 (7), 928-932.

13. Robertson, K.R., Smurzynski, M., Parsons, T.D., Wu, K., Bosch, R.J., Wu, J., ... \& Ellis, R.J. (2007). The prevalence and incidence of neurocognitive impairment in the HAART era. Aids, 21 (14), 1915-1921.

14. Antinori, A., Arendt, G., Becker, J.T., Brew, B.J., Byrd, D.A., Cherner, M., ... \& Gisslen, M. (2007). Updated research nosology for HIV-associated neurocognitive disorders. Neurology, 69 (18), 1789-1799.

15. Underwood, J., \& Winston, A. (2016). Guidelines for evaluation and management of cognitive disorders in HIV-positive individuals. Current HIVIAIDS Reports, 13 (5), 235-240.

16. (2014). World Health Organization. Consolidated guidelines on HIV prevention, diagnosis, treatment and care for key populations. Geneva: World Health Organization.

\section{ОСОБЕННОСТИ НАРУШЕНИЯ КОГНИТИВНЫХ ФУНКЦИЙ У ПАЦИЕНТОВ С ВИЧ-ИНФЕКЦИЕЙ, КОТОРЫЕ НАХОДЯТСЯ ПОД АМБУЛАТОРНЫМ НАБЛЮДЕНИЕМ}

Л.Р. Шостакович-Корецкая ${ }^{1}$, Е.Ю. Литвин ${ }^{1}$, А.А. Белоконь ${ }^{1}$, И.П. Мишкойㄹ, И.В. Чухалова ${ }^{2}$, Е.О. Лесничая ${ }^{3}$

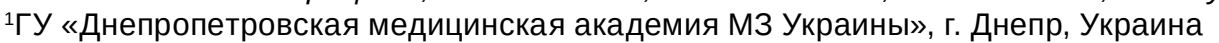

${ }^{2}$ КУ «Днепропетровский областной центр профилактики и борьбы со СПИДом», г. Днепр, Украина

${ }^{3}$ КУ «Днепропетровская городская клиническая больница № 21 им. проф. Е. Г. Попковой» ДОС», г. Днепр, Украина

Цель: определить наличие когнитивных нарушений и факторы возможного влияния на когнитивную фрункцию у пациентов с ВИЧ, которые находятся под диспансерным наблюдением.

Материалы и методы. В исследование были включены 95 пациентов с подтвержденной ВИЧинфрекцией без клинических признаков заболеваний ЦНС. Оценка ментального статуса проводилась по результатам прохождения 2 тестов: MMSE и «рисования часов».

Результаты. Выявлено, что уменьшение частоты когнитивных расстройств коррелировало с продолжительностью АРТ- коэффициент корреляции для балльной оценки по шкале MMSE cocтавил rs $=+0,27$, $\mathrm{p}<0,01$, для теста «рисования часов» - rs=+0,22, $<<0,05$. Определена тенденция к увеличению частоты когнитивных нарушений при применении эфавиренза. Установлено, что применение заместительной поддерживающей терапии (метадон) у потребителей наркотиков уменьшало относительный риск развития когнитивных расстройств $(p<0,01)$. Определена связь данных расстройств с вирусной нагрузкой в динамике наблюдения ( $r s=0,20, p<0,05$ для теста MMSE).

Выводы. Нарушение когнитивной функции имеет место у ВИЧ-позитивных пациентов на ранней стадии ВИЧ-инфекции.

КЛЮЧЕВЫЕ СЛОВА: ВИЧ-инфекция; когнитивные нарушения; антиретровирусная терапия; заместительная поддерживающая терапия. 
PARTICULARITIES OF COGNITIVE FUNCTION DISTURBANCES IN PATIENTS WITH HIV INFECTION, WHO ARE FOLLOWED AT OUTPATIENT BASIS

L.R. Shostakovych-Koretskaia', K.Yu. Lytvyn', O.O. Bilokon ${ }^{1}$, I.P. Mishkoi', I.V. Chukhalova', O.O. Lesnycha ${ }^{3}$

${ }^{1}$ Dnipropetrovsk Medical Academy of Ministry of Health of Ukraine, Dnipro, Ukraine

${ }^{2}$ Dnipropetrovsk Regional Centre for the Prevention and Management of AIDS, Dnipro, Ukraine.

${ }^{3}$ Prof. Ye. Popkov Dnipropetrovsk Municipal Clinical Hospital No. 21, Dnipropetrovsk Municipal Centre for the

Prevention and Management of AIDS, Dnipro, Ukraine.

Purpose: to determine the presence of cognitive impairment and factors of possible influence on the cognitive function among HIV patients who are under the outpatient follow-up.

Materials and Methods. The study involved 95 patients of age with confirmed HIV infection without clinical signs of CNS diseases. The assessment of the mental status was carried out on the basis of two tests: MMSE and "drawing of the clock".

Results. It was found that the decrease in the frequency of cognitive disorders correlated with the duration of ART - the correlation coefficient for the score on the MMSE scale was rs $=+0.27, p<0.01$, for the "clock drawing" test $-r s=+0.22, p<0.05$. There was a tendency to increase of the incidence of cognitive impairment at the use of efavirenz. It has been established that the use of substitution maintenance therapy (methadone) in drug users reduced the relative risk of developing cognitive impairment $(p<0.01)$. The presence of a probable connection with the viral load in dynamics ( $r s=-0.20, p<0.05$ for the MMSE test) has been determined.

Conclusions. Disturbances of cognitive function occur in patients with HIV infection at an early stage of HIV infection. therapy

KEY WORDS: HIV infection; cognitive impairment; antiretroviral therapy; substitution maintenance

Рукопис надійшов до редакції 23.05.2018 p.

\section{Відомості про авторів:}

Шостакович-Корецька Людмила Романівна - доктор медичних наук, професор, завідувач кафедри інорекційних хвороб ДМА.

Литвин Катерина Юріївна - доцент кафедри інфекційних хвороб ДМА; тел.: +38(067) 739-09-51.

Білоконь Олександр Олександрович - клінічний ординатор кафедри інфекційних хвороб ДМА; тел.: +38(096) 906-00-47.

Мішкой Ірина Петрівна - лікар-інфекціоніст К3 «Дніпропетровський обласний центр з профрілактики та боротьби зі СНІДом»; тел.: +38(096) 906-62-74.

Чухалова Ірина Віталіївна - головний лікар КЗ «Дніпропетровський обласний центр з профілактики та боротьби зі СНІДом»; тел.: +38(675) 68-10-01.

Ліснича Олена Орестівна - лікар-інфекціоніст, завідувач Дніпропетровського міського центру 3 профрілактики та боротьби зі СНІДом КЗ «Дніпропетровська міська клінічна лікарня № 21 ім. профр. Є. Г. Попкової» ДОР»; тел.: +38(099) 088-17-54. 